Moksoilable online at: www.jmi.mikoina.or.id

\title{
Jamur Makro Berpotensi Pangan dan Obat di Kawasan Cagar Alam Lembah Anai dan Cagar Alam Batang Palupuh Sumatera
}

\section{Potential of macrofungi as a Food and Medicinal source from Lembah Anai and Batang Palupuh Natural reserve, West Sumatera}

\author{
Noverita1, Sinaga $\mathbf{E}^{2,3}$, Setia $\mathbf{T M}^{2,3}$ \\ ${ }^{1}$ Fakultas BiologiUniversitas Nasional, Jakarta \\ ${ }^{2}$ Sekolah Pascasarjana Prodi Magister Biologi Universitas Nasional, Jakarta \\ ${ }^{3}$ Lembaga Penelitian dan Pengabdian Pada Masyarakat Universitas Nasional
}

Noverita, Sinaga E, Setia TM. 2017 - Inventarisasi Makrofungi Berpotensi Pangan Dan Obat Di Kawasan Cagar Alam Lembah Anai dan Cagar Alam Batang Palupuh Sumatera. Jurnal Mikologi Indonesia 1(1), 15-27.

\begin{abstract}
Abstrak
Telah dilakukan Penelitian di Kawasan Cagar Alam Lembah Anai dan Cagar Alam Batang Palupuh, Sumetera Barat, dengan tujuan mendapatkan data jenis-jenis jamur makro di kedua kawasan tersebut, dan data-data jenis jamur makro yang berpotensi baik sebaga bahan pangan dan obat, menggunakan metode koleksi langsung dengan memodifikasi jalur menggunakan plot. Dalam eksplorasi ini telah ditemukan sebanyak 112 jenis makrofungi (63 jenis di Kawasan Cagar Alam Lembah Anai, 58 jenis di Kawasan Cagar Alam Batang Palupuah). Jamur makro yang ditemukan didominasi dari bangsa Aphylloporales dengan jenis-jenisnya antara lain Amauroderma rugosum, Cymatoderma sp., Fomitopsis sp., Ganoderma spp., Heterobasidion annosum, Microphorus spp., Polyporus spp., Rigidoporus spp., dan Trametes spp. Kelompok berikutnya yang mendominasi adalah dari bangsa Agaricales, dengan jenisjenisnya antara lain Amanita spp., Agaricus spp., Clytocibe spp., Entoloma spp., Filoboletus spp., Hygrocybe spp., Lepiota spp., Omphalina spp., Marasmius spp., Marasmiellus spp., dan Russula spp. Jenis-jenis yang berpotensi sebagai sumber pangan dari kawasan ini adalah Auricularia auricula, Auricularia delicata, Agaricus spp., Boletellus spp., Calvatia excipuliformis, Cantharellus cibarius, Cookeina speciosa, Fistulina sp., Hygrocybe sp., Lentinus sajor-caju, Marasmiellus ramealis, Russula fragilis, dan Pluteus cervinus. Sementara jenisjenis yang berpotensi sebagai bahan obat adalah Amauroderma rugosum, Ganoderma lucidum, Ganoderma pfeifferi, Ganoderma resinaceum, Microphorus spp., Polyporus spp., Trametes spp., dan Xylaria spp.
\end{abstract}

Kata kunci - bioteknologi - diversitas jamur - makrofungi - Indonesia - cagar alam

\begin{abstract}
Inventarisation of macrofungi in the Nature Reserve Lembah Anai and Batang Palupuh, West Sumatra, has been conducted. The purpose of this study was to determine the macrofungal diversity in both areas, and to know species diversity of macrofungi have potential as a food and medicinal. The macrofungi specimens were collected through transect line in particular plot. About 112 species of macrofungi were collected (63 species in Lembah Anai Nature
\end{abstract}


Reserve, 58 species in the Nature Reserve Batang Palupuh). Member of Aphylloporales (Amauroderma rugosum, Cymatoderma sp., Fomitopsis sp., Ganoderma spp., Heterobasidion annosum, Microphorus spp., Polyporus spp., Rigidoporus spp., and Trametes spp.) and Agaricales (Amanita spp., Agaricus spp., Clytocibe spp., Entoloma spp., Filoboletus spp., Hygrocybe spp., Lepiota spp., Omphalina spp., Marasmius spp., Marasmiellus spp., and Russula sp.) were found dominant. Food macrofungi in this area includes Auricularia auricula, Auricularia delicata, Agaricus spp., Boletellus spp., Calvatia excipuliformis, Cantharellus cibarius, Cookeina speciosa, Fistulina sp., Hygrocybe sp., Lentinus sajor-caju, Marasmiellus ramealis, Russula fragilis, and Pluteus cervinus. Medicinal macrofungi found in both areas include Amauroderma rugosum, Ganoderma lucidum, Ganoderma pfeifferi, Ganoderma resinaceum, Microphorus spp., Polyporus spp., Trametes spp., and Xylaria spp.

Key words - biotechnology - fungal diversity - Indonesia - macrofungi - natural sanctuary

\section{Pendahuluan}

Indonesia diakui sebagai salah satu negara dengan megadiversitas flora dan fauna, termasuk fungi, tertinggi kedua setelah Brazil (Hilman \& Romadoni 2001). Kawasan Cagar Alam Lembah Anai dan Cagar Alam Batang Palupuh merupakan dua kawasan hutan cagar alam yang terletak di Propinsi Sumatra Barat, tepatnya Kabupaten Tanah Datar (Cagar Alam Lembah Anai) dan Kabupaten Agam (Cagar Alam Batang Palupuh) (BKSDA Sumbar 2007). Kedua kawasan ini menjadi pilihan dalam penelitian ini, karena merupakan kawasan dengan hutan tropis yang lebat dan unik.

Data pasti mengenai biodiversitas fungi di Indonesia, terutama jamur makro yang berpotensi sebagai makanan dan sumber obat-obatan belum banyak dilaporkan. Jusana dkk (2013) telah melakukan penelitian Kawasan Cagar Alam Lembai Anai, dan menemukan sebanyak 29 jenis jamur makro yang terbagi ke dalam 2 kelas, 4 ordo, 11 familia dan 20 genus, akan tetapi penelitian ini belum memadai dan tidak melihat potensi dari jamur makro yang ada di kawasan tersebut. Sementara itu di kawasan Cagar Alam Batang Palupuh belum ada laporan mengenai keberadaan jamur makro.

Banyak cara yang dapat dilakukan untuk menjawab tantangan tersebut, salah satunya adalah melakukan studi keanekaragaman jamur makro yang ada di kawasan-kawasan dan hutan-hutan yang ada di Indonesia, agar dapat mengungkap kekayaan alam Indonesia secara pasti. Berdasarkan latar belakang dan permasalahan tersebut, maka penelitian ini dilakukan dengan tujuan untuk mendapatkan data jenis-jenis jamur makro di kawasan tersebut, dan memperoleh data mengenai jenis-jenis jamur makro yang berpotensi baik sebagai bahan pangan dan obat. Manfaat yang diharapkan dalam penelitian ini adalah mengetahui jumlah jenis makrofungi secara keseluruhan dan jumlah jenis yang berpotensi pangan dan obat yang nantinya dapat diupayakan untuk dibudidayakan sebagai alternatif dalam peningkatan taraf hidup masyarakat.

\section{Metoda Penelitian}

\section{Penentuan Batasan Lokasi Sampling di Lapangan}

Penelitian ini dilakukan di kawasan cagar alam Lembah Anai dan kawasan cagar alam Batang Palupuh, Sumatera Barat. Penelitian dimulai dari penentuan lokasi sampling di lapangan dengan tujuan supaya terwakili wilayah pengambilan sampel sesuai dengan kondisi substrat. Lokasi penelitian di setiap kawasan yang direncanakan masing-masing terdiri atas 3 jalur yaitu jalur di sepanjang pinggiran hutan /perkampungan untuk mewakili daerah terbuka, jalur sepanjang hutan untuk mewakili daerah tertutup dan jalur di sekitar pinggiran sungai mewakili daerah yang lembah dan basah. Penentuan lokasi ini dibuat berdasarkan peta lokasi masing-masing kawasan atau hutan lindung, sesuai dengan lokasi pengambilan sampel. 


\section{Pengambilan Data}

Pengambilan data dilakukan dengan metode koleksi langsung yang dimodifikasi menggunakan plot. Metode ini dilakukan dengan membuat plot disepanjang kanan dan kiri jalur pengamatan seluas $20 \times 10 \mathrm{~m}$, dengan interval jarak antar plot $10 \mathrm{~m}$. pada masing-masing plot yang telah dibuat dilakukan pengamatan dan pencatatan terhadap jenis jamur yang ditemukan, begitu juga dengan yang ada di setiap interval.

\section{Pengamatan Morfologi Tubuh Buah}

Pengamatan morfologi dilakukan dengan metode deskriptif. Terhadap sampel makrofungi yang ditemukan di lapangan dilakukan pengamatan bentuk tubuh buah, ukuran, warna, tekstur, sifat hidup (sendiri-sendiri atau berkelompok), jumlah individu dan untuk yang berkoloni jumlah koloni, substrat tumbuh (pohon atau ranting hidup, pohon atau ranting mati, tanah, serasah atau substrat lain).

\section{Pembuatan Jejak Spora}

Jejak spora dibuat dengan cara memotong bagian tudung dari tubuh buah, kemudian diletakkan dengan posisi telungkup di atas kertas karton dua warna (gelap dan terang) yang sudah disiapkan di dalam wadah (kotak). Bagian tudung tersebut kemudian dibiarkan selama 24 jam. Jejak spora yang terbentuk kemudian dimasukkan ke dalam botol yang berisi larutan lactophenol, selanjutnya diamati di laboratorium untuk melihat bentuk sporanya.

\section{Isolasi Tubuh Buah}

Isolasi tubuh buah dilakukan terhadap jamur makro yang berpotensi sebagai bahan pangan, tujuannya untuk mendapatkan kultur isolat yang nantinya dilakukan budi daya di laboratorium. Pengambilan tubuh buah dilakukan dengan cara: bagian dalam dari tangkai tubuh buah dibuka atau dibelah, kemudian diambil menggunakan pinset dan ditanamkan ke dalam media PDA, selanjutnya diinkubasi pada suhu kamar sampai koloninya tumbuh. Untuk sampel jamur makro yang berupa lembaran tipis seperti jamur kuping, pengambilan tubuh buah dilakukan dengan cara; bagian tubuh yang berupa lembaran dipotong dan disterilkan dengan menggunakan alkohol $70 \%$, selanjutnya dibilas dengan akuades steril, kemudian diambil mengunakan pingset dan ditanamkan ke dalam media PDA, diinkubasikan pada suhu kamar sampai koloninya tumbuh (Beauséjour,1999).

\section{Pengukuran Parameter Lingkungan}

Pengukuran parameter lingkungan meliputi suhu, $\mathrm{pH}$ tanah, dan kelembaban udara. Data faktor lingkungan ini diambil dari pagi hari sampai selesai pengambilan sampel.

\section{Identifikasi makrofungi}

Identifikasi jamur dilakukan berdasarkan data dari hasil pengamatan lapangan dan data dari hasil pengamatan laboratorium yang meliputi; sifat (parasit, saprofit), keberadaan tumbuh (sendiri atau koloni), substrat tempat tumbuh (kayu, ranting hidup atau mati, serasah, tanah), bentuk tubuh buah, warna, tekstur, kedudukan tangkai, komponen lain penyusun tangkai, ciri lain penyusun lamela, pori atau bagian lain penghasill spora, bentuk spora, ukuran, warna dan ornamen lainnya pada spora, dan ciri-ciri spesifik lainnya. Data yang diperoleh ini selanjutnya dicocokkan dengan buku-buku identifikasi fungi makroskopis, sampai ditemukan nama jenisnya. Buku rujukan untuk identifikasi yang digunakan antara lain adalah Guide To Mushrooms (Pacioni, 1994), Working with Mycorrhiza in Foresty and Agriculture (Brundrett \& Baugher, 2008), How To Identify Mushrooms To Genus I ( Largent,1973), Agaric Flora of The Lesser Antilles (Pegler, 1983), dan A Preliminary Polypore Flora of East Africa (Johansen and Ryvardern, 1980). 


\section{Hasil}

\section{Kondisi Lingkungan Kawasan Cagar Alam Lembah Anai dan Kawasan Cagar Alam Batang Palupuh}

Hasil pengamatan kondisi lingkungan dan kondisi subtrat di kedua kawasan penelitian yaitu kawasan cagar alam Lembah Anai dan Batang Palupuh di tampilkan pada tabel 1, gambar 1 dan gambar 2.

Tabel 1. Data kondisi lingkungan di wilayah kawasan cagar alam Lembah Anai dan kawasan cagar alam Batang Palupuh, Sumatera Barat.

\begin{tabular}{llcc}
\hline No. & Parameter Lingkungan & \multicolumn{2}{c}{ Nilai Parameter } \\
\cline { 3 - 4 } & & Lembah Anai & Batang Palupuh \\
\hline 1 & pH Tanah & $6,7-7$ & $6,6-7$ \\
2 & Kelembaban $(\%)$ & $42-65$ & $40-55$ \\
3 & Suhu $\left({ }^{\circ} \mathrm{C}\right)$ & $27-32$ & $26-30$ \\
4 & Intensitas Cahaya (Lux) & $101-3055$ & $273-2920$ \\
5 & Tutupan Tajuk & $65,6-90,8$ & $63,8-87,79$ \\
\hline
\end{tabular}

Jumlah jenis Jamur Makro di Kawasan Cagar Alam Lembah Anai dan Cagar Alam Batang Palupuh Sumatera Barat

Ditemukan sebanyak 117 jenis jamur makro di dua cagar alam kawasan di Sumatera Barat, yaitu kawasan cagar alam Lembah Anai (61 jenis, yang terdiri dari 3 jenis Ascomycota, dan 58 jenis Basidiomycota) dan Batang Palupuah (56 jenis, yang terdiri dari 3 jenis Ascomycota dan 53 jenis Basidiomycota) (gambar 3).

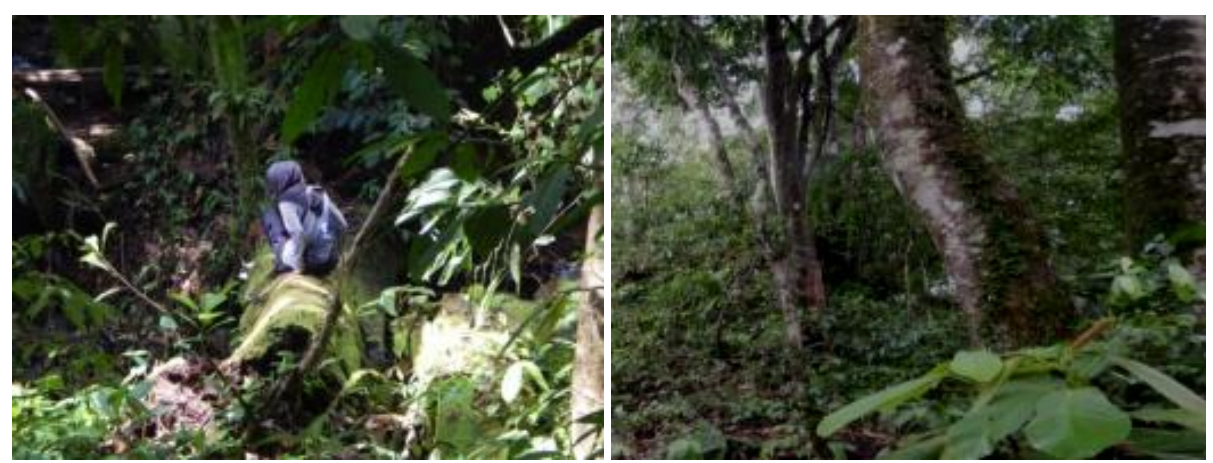

Gambar 1. Kawasan hutan cagar alam Lembah Anai, Sumatera Barat.

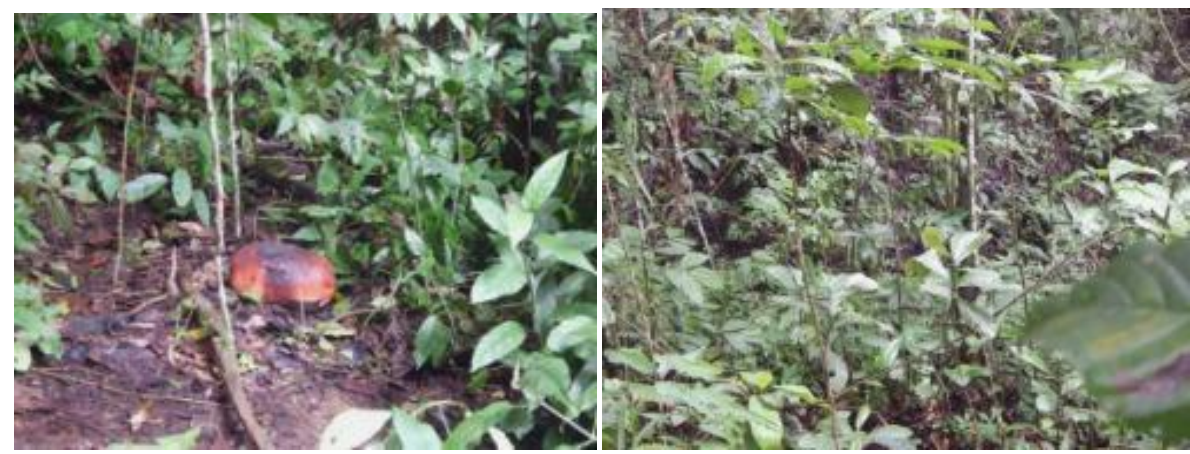

Gambar 2. Kawasan hutan cagar alam Batang Palupuah, Sumatera Barat. 
Jenis-Jenis Jamur Makro yang Ditemukan Di Kawasan Cagar Alam Lembah Anai dan Cagar Alam Palupuh Sumatera Barat

Jenis-jenis jamur makro yang ditemukan di kedua kawasan tersebut ditampilkan pada Tabel 2 dan 3.

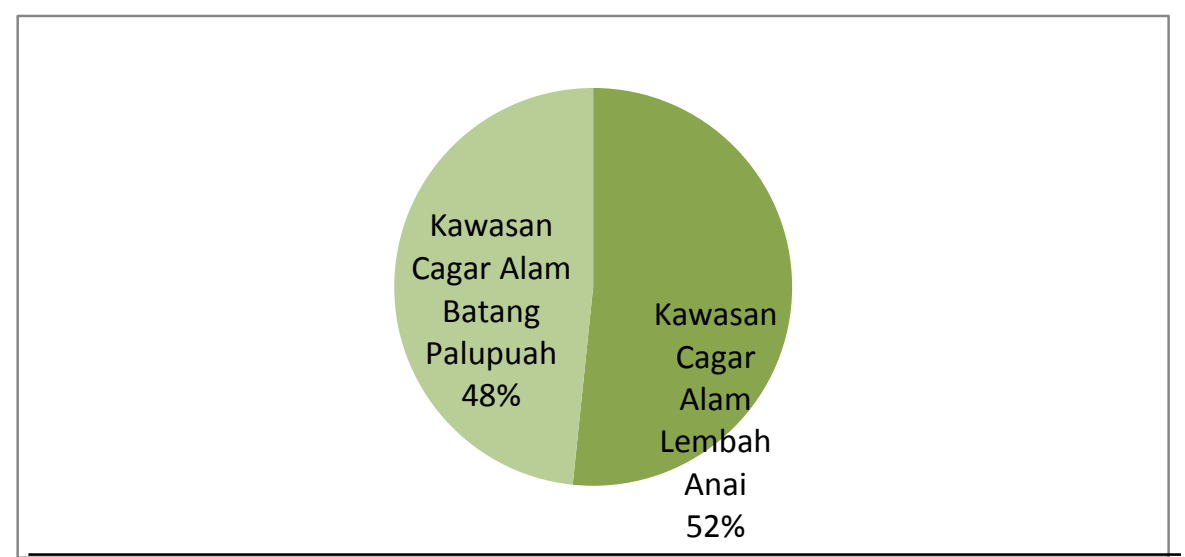

Gambar 3. Diagram jumlah jenis jamur makro di kawasan cagar alam Lembah Anai dan cagar alam Batang Palupuh, Sumatera Barat.

Tabel 2. Jenis-jenis jamur makro yang ditemukan di kawasan cagar alam Lembah Anai.

\begin{tabular}{|c|c|c|c|c|}
\hline No & Jenis & Suku & Bangsa & Filum \\
\hline 1 & Amanita sp.1 & Amanitaceae & Agaricales & Basidiomycota \\
\hline 2 & $\begin{array}{l}\text { Amauroderma } \\
\text { rugosum }\end{array}$ & Ganodermataceae & Aphyllophorales & Basidiomycota \\
\hline 3 & Agaricus sp.1 & Agaricaceae & Agaricales & Basidiomycota \\
\hline 4 & Boletellus ananas & Boletaceae & Boletales & Basidiomycota \\
\hline 5 & Boletus sp.1 & Boletaceae & Boletales & Basidiomycota \\
\hline 6 & Cantharellus cibarius & Chantharellaceae & Cantharellales & Basidiomycota \\
\hline 7 & Cookeina speciosa & Sarcoscyphaceae & Pezizales & Ascomycota \\
\hline 8 & Cymatoderma sp.1 & Meliaceae & Aphyllophorales & Basidiomycota \\
\hline 9 & Entoloma sp.1 & Entolomataceae & Agaricales & Basidiomycota \\
\hline 10 & Entoloma sp.2 & Entolomataceae & Agaricales & Basidiomycota \\
\hline 11 & Filoboletus sp.1 & Boletaceae & Boletales & Basidiomycota \\
\hline 12 & Filoboletus sp.2 & Boletaceae & Boletales & Basidiomycota \\
\hline 13 & Filoboletus sp.3 & Boletaceae & Boletales & Basidiomycota \\
\hline 14 & Fistulina hepatica & Fistulinaceae & Aphyllophorales & Basidiomycota \\
\hline 15 & Fomitopsis sp. & Polyporaceae & Aphyllophorales & Basidiomycota \\
\hline 16 & $\begin{array}{l}\text { Ganoderma } \\
\text { applanatum }\end{array}$ & Ganodermataceae & Aphyllophorales & Basidiomycota \\
\hline 17 & G. pfeifferi & Ganodermataceae & Aphyllophorales & Basidiomycota \\
\hline 18 & G.resinaceum & Ganodermataceae & Aphyllophorales & Basidiomycota \\
\hline 19 & $\begin{array}{l}\text { Heterobasidion } \\
\text { annosum }\end{array}$ & Polyporaceae & Aphyllophorales & Basidiomycota \\
\hline 20 & Hygrocybe & Hygrophoraceae & Agaricales & Basidiomycota \\
\hline 21 & Lentinus sajor-caju & Polyporaceae & Aphyllophorales & Basidiomycota \\
\hline 22 & Lepiota cristata & Agaricaceae & Agaricales & Basidiomycota \\
\hline 23 & Lepiota sp. 1 & Agaricaceae & Agaricales & Basidiomycota \\
\hline 24 & Lepiota sp. 2 & Agaricaceae & Agaricales & Basidiomycota \\
\hline
\end{tabular}


Noverita dkk, 2017

\begin{tabular}{|c|c|c|c|c|}
\hline 25 & Lepiota $\mathrm{sp} .3$ & Agaricaceae & Agaricales & Basidiomycota \\
\hline 26 & Lepiota sp.4 & Agaricaceae & Agaricales & Basidiomycota \\
\hline 27 & Loreleia sp. & Repetobasidiaceae & Hymenochaetales & Basidiomycota \\
\hline 28 & Lycoperdon sp.1 & Lycoperdaceae & Agaricales & Basidiomycota \\
\hline 29 & Lycoperdon sp.2 & Lycoperdaceae & Agaricales & Basidiomycota \\
\hline 30 & $\begin{array}{l}\text { Marasmiellus } \\
\text { ramealis }\end{array}$ & Marasmiaceae & Agaricales & Basidiomycota \\
\hline 31 & Marasmius sp.1 & Marasmiaceae & Agaricales & Basidiomycota \\
\hline 32 & Marasmius sp.2 & Marasmiaceae & Agaricales & Basidiomycota \\
\hline 33 & Microphorus afinitis & Polyporaceae & Aphyllophorales & Basidiomycota \\
\hline 34 & M. flabeliformis & Polyporaceae & Aphyllophorales & Basidiomycota \\
\hline 35 & M. vernicipes & Polyporaceae & Aphyllophorales & Basidiomycota \\
\hline 36 & $\begin{array}{l}\text { Microporus } \\
\text { xanthopus }\end{array}$ & Polyporaceae & Aphyllophorales & Basidiomycota \\
\hline 37 & Microporus sp.1 & Polyporaceae & Aphyllophorales & Basidiomycota \\
\hline 38 & Microporus sp.2 & Polyporaceae & Aphyllophorales & Basidiomycota \\
\hline 39 & Microporus sp.3 & Polyporaceae & Aphyllophorales & Basidiomycota \\
\hline 40 & Mycena sp. & Mycenaceae & Agaricales & Basidiomycota \\
\hline 41 & Omphalina sp.1 & Tricholomataceae & Agaricales & Basidiomycota \\
\hline 42 & Omphalina sp.2 & Tricholomataceae & Agaricales & Basidiomycota \\
\hline 43 & Omphalina sp.3 & Tricholomataceae & Agaricales & Basidiomycota \\
\hline 44 & $\begin{array}{l}\text { Oudemansiella } \\
\text { mucida }\end{array}$ & Physalacriaceae & Agaricales & Basidiomycota \\
\hline 45 & Panellus sp. & Mycenaceae & Agaricales & Basidiomycota \\
\hline 46 & Polyporus badius & Polyporaceae & Aphyllophorales & Basidiomycota \\
\hline 47 & Polyporus sp.1 & Polyporaceae & Aphyllophorales & Basidiomycota \\
\hline 48 & Polyporus sp.2 & Polyporaceae & Aphyllophorales & Basidiomycota \\
\hline 49 & Polyporus sp.3 & Polyporaceae & Aphyllophorales & Basidiomycota \\
\hline 50 & Rigidoporus sp. & Polyporaceae & Aphyllophorales & Basidiomycota \\
\hline 51 & Russula fragilis & Russulaceae & Russulales & Basidiomycota \\
\hline 52 & Russula sp. 1 & Russulaceae & Russulales & Basidiomycota \\
\hline 53 & Stereopsis sp. & Stereopsidaceae & Stereopsidales & Basidiomycota \\
\hline 54 & Strobilomyces sp. & Boletaceae & Boletales & Basidiomycota \\
\hline 55 & Trametes pubescens & Polyporaceae & Aphyllophorales & Basidiomycota \\
\hline 56 & Trametes hirsuta & Polyporaceae & Aphyllophorales & Basidiomycota \\
\hline 57 & Trametes vesicolor & Polyporaceae & Aphyllophorales & Basidiomycota \\
\hline 58 & Trametes sp. & Polyporaceae & Aphyllophorales & Basidiomycota \\
\hline 59 & Trametes sp.2 & Polyporaceae & Aphyllophorales & Basidiomycota \\
\hline 60 & Xylaria hypoxylon & Xylariaceae & Xylariales & Ascomycota \\
\hline 61 & Xylaria polymorpha & Xylariaceae & Xylariales & Ascomycota \\
\hline
\end{tabular}

Tabel 3. Jenis-jenis jamur makro yang ditemukan di kawasan cagar alam Batang Palupuah.

\begin{tabular}{|l|l|l|l|l|}
\hline No & Jenis & Suku & Bangsa & Filum \\
\hline 1 & Auricularia auricula & Auriculariaceae & Auriculariales & Basidiomycota \\
\hline 2 & Auricularia delicata & Auriculariaceae & Auriculariales & Basidiomycota \\
\hline
\end{tabular}


Noverita dkk, 2017

\begin{tabular}{|c|c|c|c|c|}
\hline 3 & Amanita sp.2 & Amanitaceae & Agaricales & Basidiomycota \\
\hline 4 & Agaricus sp.2 & Amanitaceae & Agaricales & Basidiomycota \\
\hline 5 & Agaricus sp.3 & Amanitaceae & Agaricales & Basidiomycota \\
\hline 6 & Calvatia excipuliformis & Agaricaceae & Agaricales & Basidiomycota \\
\hline 7 & Clavulina sp. & Clavulinaceae & Cantharellales & Basidiomycota \\
\hline 8 & Clitocybe sp. & Tricholomataceae & Agaricales & Basidiomycota \\
\hline 9 & Cookeina tricholoma & Sarcoscyphaceae & Pezizales & Ascomycota \\
\hline 10 & Crepidotus sp.1 & Crepidotaceae & Agaricales & Basidiomycota \\
\hline 11 & Crepidotus sp.2 & Crepidotaceae & Agaricales & Basidiomycota \\
\hline 12 & Cymatoderma sp.1 & Meruliaceae & Aphyllophorales & Basidiomycota \\
\hline 13 & Entoloma sp. & Entolomataceae & Agaricales & Basidiomycota \\
\hline 14 & Dacrymyces sp. & Dacrymycetaceae & Dacrymycetales & Basidiomycota \\
\hline 15 & Favolaschia & Mycenaceae & Agaricales & Basidiomycota \\
\hline 16 & Fomitopsis sp. & Polyporaceae & Aphyllophorales & Basidiomycota \\
\hline 17 & Galerina & Cortinariaceae & Agaricales & Basidiomycota \\
\hline 18 & Ganoderma lucidum & Ganodermataceae & Aphyllophorales & Basidiomycota \\
\hline 18 & G.resinaceum & Ganodermataceae & Aphyllophorales & Basidiomycota \\
\hline 20 & Gerronema sp.1 & Marasmiaceae & Agaricales & Basidiomycota \\
\hline 21 & Gerronema sp.2 & Marasmiaceae & Agaricales & Basidiomycota \\
\hline 22 & Geastrum saccatum & Geatraceae & Geastrales & Basidiomycota \\
\hline 23 & Hericium sp.1 & Hericiaceae & Russulales & Basidiomycota \\
\hline 24 & Hygrocybe sp.2 & Hygrophoraceae & Agaricales & Basidiomycota \\
\hline 25 & Hymenochaete sp. & Hymenochaetaceae & Aphyllophorales & Basidiomycota \\
\hline 26 & Inonotus sp. & Hymenochaetaceae & Aphyllophorales & Basidiomycota \\
\hline 27 & Lepiota sp.5 & Agaricaceae & Agaricales & Basidiomycota \\
\hline 28 & Marasmiellus sp.3 & Marasmiaceae & Agaricales & Basidiomycota \\
\hline 29 & Marasmiellus sp.2 & Marasmiaceae & Agaricales & Basidiomycota \\
\hline 30 & Marasmiellus sp.3 & Marasmiaceae & Agaricales & Basidiomycota \\
\hline 31 & Marasmiellus sp.4 & Marasmiaceae & Agaricales & Basidiomycota \\
\hline 32 & Marasmiellus sp.5 & Marasmiaceae & Agaricales & Basidiomycota \\
\hline 33 & M. torquescens & Marasmiaceae & Agaricales & Basidiomycota \\
\hline 34 & Marasmius sp. 3 & Marasmiaceae & Agaricales & Basidiomycota \\
\hline 35 & Microphorus afinitis & Polyporaceae & Aphyllophorales & Basidiomycota \\
\hline 36 & M. xanthopus & Polyporaceae & Aphyllophorales & Basidiomycota \\
\hline 37 & Microphorus sp.1 & Polyporaceae & Aphyllophorales & Basidiomycota \\
\hline 38 & Omphalina sp.4 & Tricholomataceae & Agaricales & Basidiomycota \\
\hline 39 & Panus fasciatus & Polyporaceae & Aphyllophorales & Basidiomycota \\
\hline 40 & Panellus sp. & Mycenaceae & Agaricales & Basidiomycota \\
\hline 41 & Pholiota sp.1 & Strophariaceae & Agaricales & Basidiomycota \\
\hline 42 & Pluteus cervinus & Pluteaceae & Agaricales & Basidiomycota \\
\hline 43 & Podoscypha sp.1 & Meruliaceae & Aphyllophorales & Basidiomycota \\
\hline 44 & Podoscypha sp.2 & Meruliaceae & Aphyllophorales & Basidiomycota \\
\hline 45 & Polyporus sp.3 & Polyporaceae & Aphyllophorales & Basidiomycota \\
\hline 46 & Polyporus sp.4 & Polyporaceae & Aphyllophorales & Basidiomycota \\
\hline
\end{tabular}




\begin{tabular}{|l|l|l|l|l|}
\hline 47 & Polyporus sp.5 & Polyporaceae & Aphyllophorales & Basidiomycota \\
\hline 48 & Pterula multifida & Pterulaceae & Agaricales & Basidiomycota \\
\hline 49 & Trametes vesicolor & Polyporaceae & Aphyllophorales & Basidiomycota \\
\hline 50 & Trametes vesicolor & Polyporaceae & Aphyllophorales & Basidiomycota \\
\hline 51 & Trametes sp. 3 & Polyporaceae & Aphyllophorales & Basidiomycota \\
\hline 52 & Trametes sp.4 & Polyporaceae & Aphyllophorales & Basidiomycota \\
\hline 53 & Trametes sp.5 & Polyporaceae & Aphyllophorales & Basidiomycota \\
\hline 54 & Xerocomus sp. & Boletaceae & Boletales & Basidiomycota \\
\hline 55 & Xylaria polymorpha & Xylariaceae & Xylariales & Ascomycota \\
\hline 56 & Xylaria sp. 1 & Xylariaceae & Xylariales & Ascomycota \\
\hline
\end{tabular}

\section{Kepentingan Makrofungi di Habitat Asalnya (Hutan)}

Jamur makro pada umunya hidup sebagai saprofit di habitat asalnya dan berperan sebagai pengurai bahan-bahan organik mati seperti kayu mati atau kayu lapuk dan serasah, Beberapa contoh jamur makro yang berperan sebagai pengurai pada serasah ditampilkan pada gambar 4 dan 5. Selain itu ditemukan juga beberapa jenis jamur makro yang bersifat mikoriza (ektomikoriza) (Gambar 6).
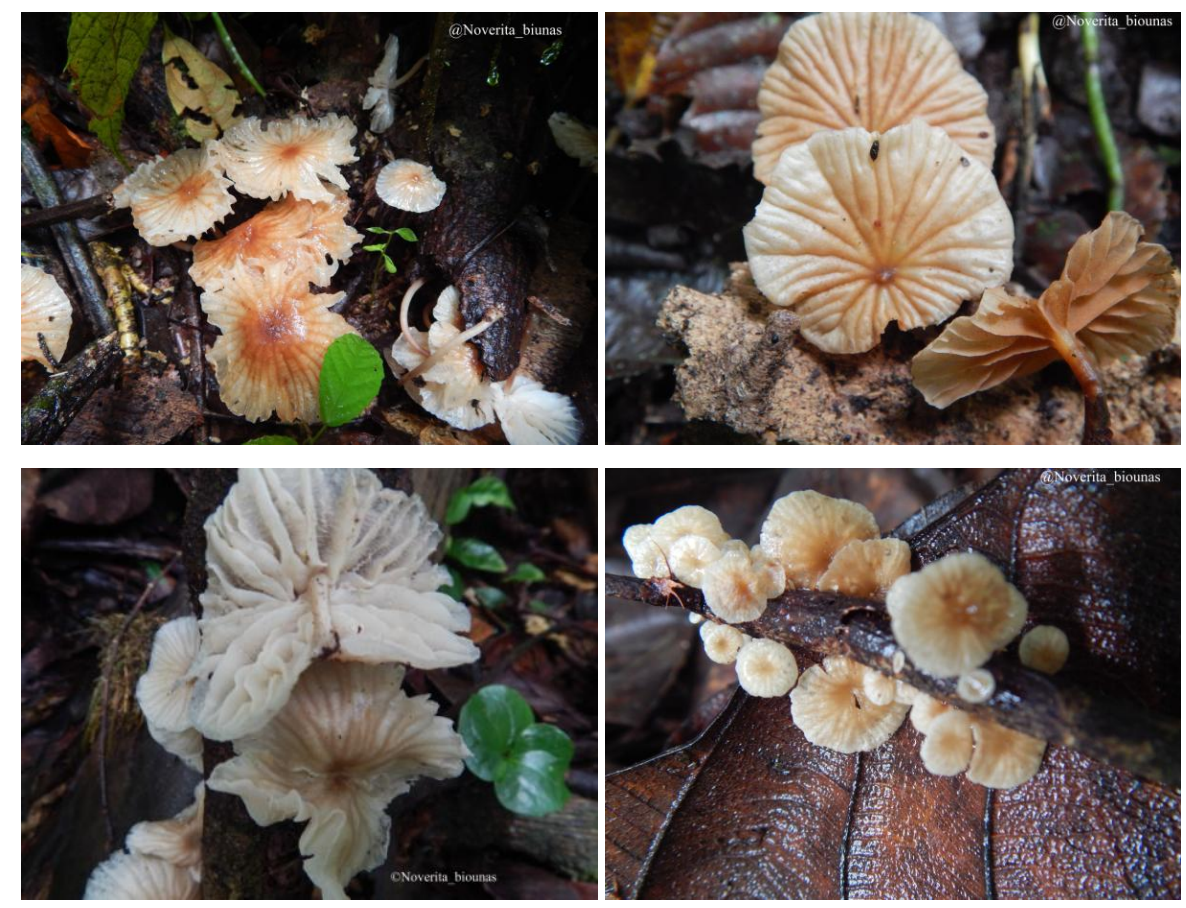

Gambar 4. Beberapa jenis Marasmius yang hidup pada serasah daun dan ranting kayu mati pada penelitian ini.

\section{Kepentingan jamur makro bagi Manusia}

Di kedua kawasan penelitian ini ditemukan beberapa jenis jamur makro yang dapat dimakan dan sangat berpotensi untuk dibudidayakan sebagai sumber makanan dan obatobatan (gambar 7 dan 8). 

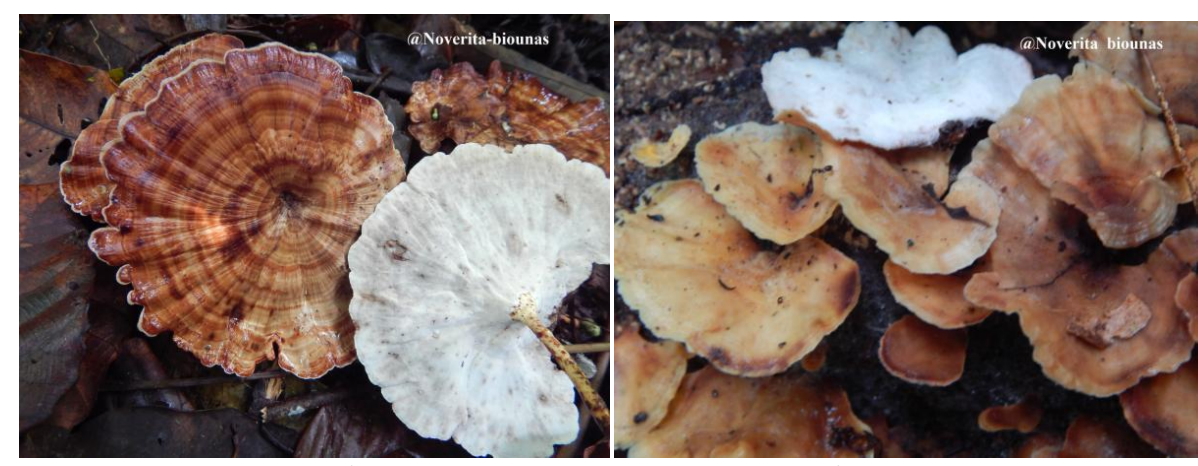

M. xanthopus
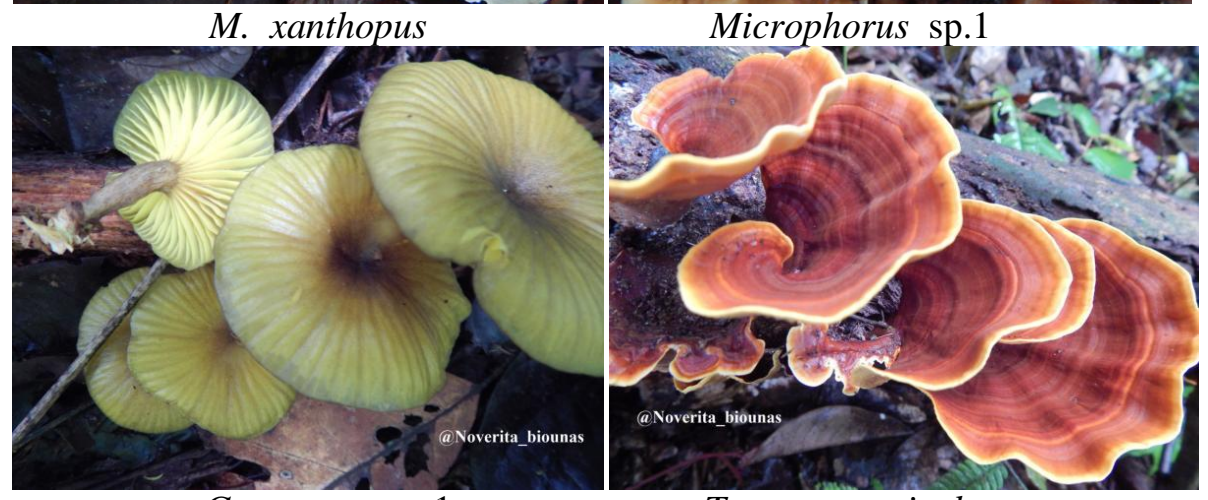

Gerronema sp.1

Trametes vesicolor

Gambar 5. Beberapa jenis jamur makro yang berperan sebagai pelapuk pada pohon, cabang dan ranting kayu mati di hutan pada penelitian ini.

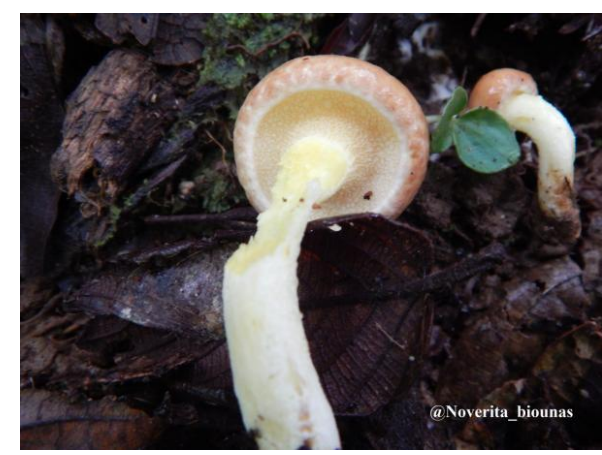

Boletus sp.1

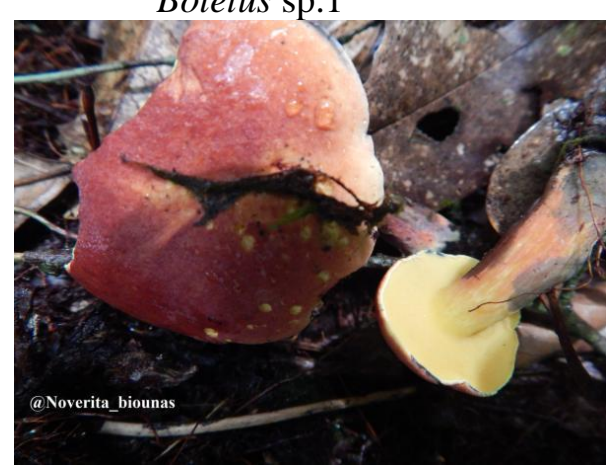

Xerocomus sp.

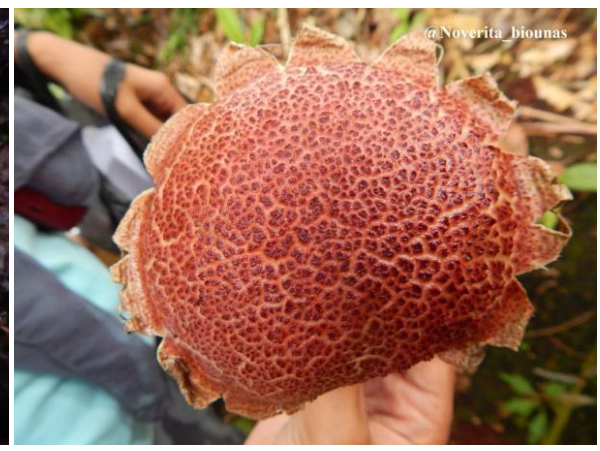

Boletellus ananas

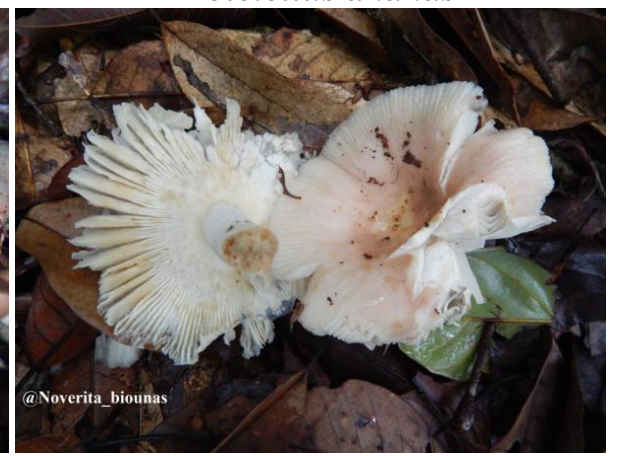

Russula sp

Gambar 6. Beberapa jenis jamur makro ektomikoriza yang ditemukan di lokasi penelitian yang tumbuh di sekitar pohon Dipterocarpaceae.

\section{Pembahasan}

Kondisi lingkungan pada kedua lokasi penelitian ini tidak jauh berbeda, bahkan cenderung berada pada kisaran yang sama, dan kisaran kondisi ini sangat baik untuk pertumbuhan makrofungi (tabel 1). Hal ini didukung oleh pernyataan Deacon (1997), intesitas 
cahaya optimum yang dibutuh untuk pertumbuhan jamur makro adalah 380-720 Lux. Suhu pertumbuhan jamur makro di alam berkisar antara $22^{\circ} \mathrm{C}$ dan $35^{\circ} \mathrm{C}$ (Arif et al. 2007). Pertumbuhan maksimal sebagian besar jamur makro anggota filum Basidiomycota berkisar pada kadar air 50-70\% (Chang \& Milles 2004), selanjutnya jamur makro yang tumbuh di hutan pada umumnya berada pada kisaran pH 4-9, dengan pH optimum 5-6 (Barnes 1998).

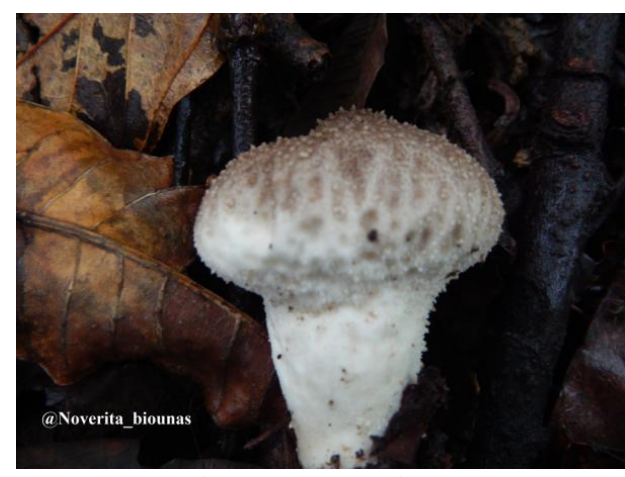

Calvatia excipuliformis

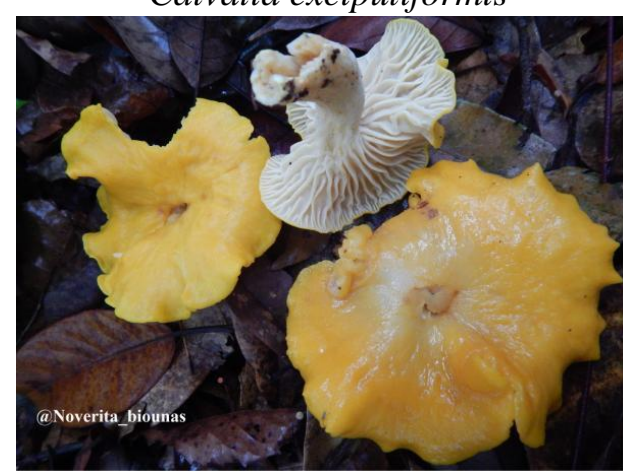

Cantharellus cibarius

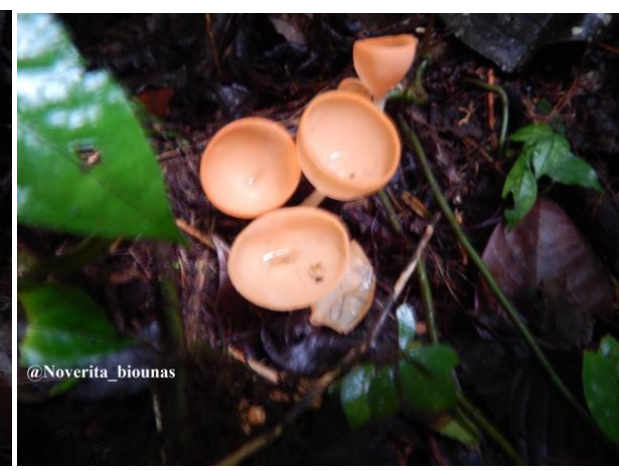

Cookeina tricholoma

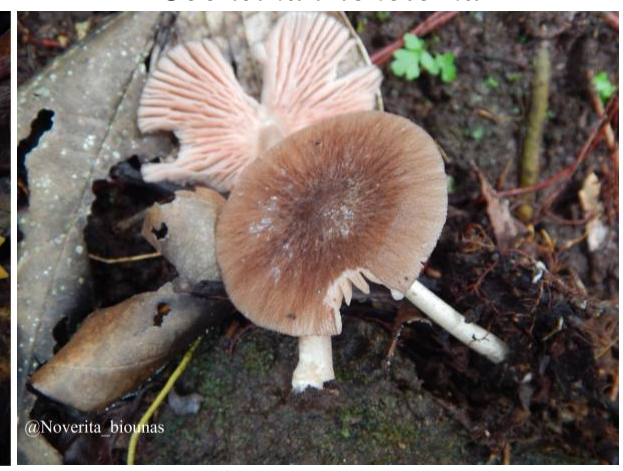

Pluteus cervinus

Gambar 7. Beberapa jenis makrofungi yang berperan sebagai bahan pangan yang ditemukan di lokasi penelitian.

Persentase jumlah jenis jamur makro yang ditemukan di kawasan Lembah Anai sedikit lebih tinggi dibandingkan dengan kawasan Batang Palupuah, yaitu selisih $4 \%$ (gambar 3). Adanya perbedaan jumlah jenis pada kedua kawasan ini sangat dipengaruhi oleh perbedaan tipe habitat atau subtrat tempat tumbuh dari makrofungi tersebut. Kawasan cagar alam Lembah Anai dari pemantauan di lapangan memiliki pohon-pohon yang tinggi, anakan pohon yang masih alami dan anakan semaian sangat rapat, serasah banyak, disamping itu udara di kawasan ini sangat lembab sehingga merupakan habitat yang sesuai untuk pertumbuhan makrofungi. Menurut BKSDA Sumbar (2007), curah hujan di cagar alam Lembah Anai cukup tinggi dan merata sepanjang tahun tanpa musim kering yang berarti yaitu 4.609,48 mm (tahunan). Temperatur rata-rata minimum $19^{\circ} \mathrm{C}$ dan maksimum $28^{\circ} \mathrm{C}$ dengan kelembaban $60 \%$ $100 \%$.

Berbeda dengan kawasan cagar alam Batang Palupuah, walaupun kawasan ini dibentuk oleh pepohonan besar dan tinggi serta liana, yang menyebabkan strata paling atas cukup padat dan tertutup kanopi dan kondisi lingkungan yang diukur sama-sama mendukung, namun strata bawah atau vegetasi dasar didominasi oleh herba, liana atau tumbuhan pemanjat dan pembelit. Keadaan ini sangat mempengaruhi keberadaan jamur makro di kawasan tersebut (Gambar 1 dan 2).

Selain mempengaruhi jumlah jenis jamur makro yang ditemukan, perbedaan habitat atau subtrat dari kedua kawasan ini juga akan mempengaruhi jeni-jenis jamur makro yang ditemukan (Tabel 2 dan 3). Dibandingkan dengan kawasan cagar alam Batang Palupuh, di 
kawasan cagar alam Lembah Anai lebih banyak ditemukan jenis jamur makro yang bersifat mikoriza (ektomikoriza) yaitu sekitar 20 jenis, diantaranya Amanita sp.1, Boletellus ananas, Boletus sp.1, Cantharellus cibarius, Entoloma sp.1, Entoloma sp.2, Lepiota cristata, Lepiota sp.1, Lepiota sp.2, Lepiota sp.3, Lepiota sp.4, Russula fragilis, Russula sp.1, dan Strobilomyces sp., sementara di kawasan cagar alam Batang Palupuh ditemukan hanya 5 jenis, yaitu Amanita sp.2, Calvatia excipuliformis, Clavulina sp., Clitocybe sp., dan Lepiota sp.5. Data ini menunjukkan bahwa hutan di kawasan cagar alam Lembah Anai memiliki banyak jenis pohon-pohon besar, dengan kondisi hutan yang tergolong subur, karena di hutan tersebut banyak ditemukan jenis mikoriza (ektomikoriza), hal ini juga sesuai dengan pematau kami selama di lapangan. Mikoriza berperan dalam rantai makanan di rizosfer akar dan memacu pertumbuhan hampir semua jenis pohon di hutan tropika Indonesia.

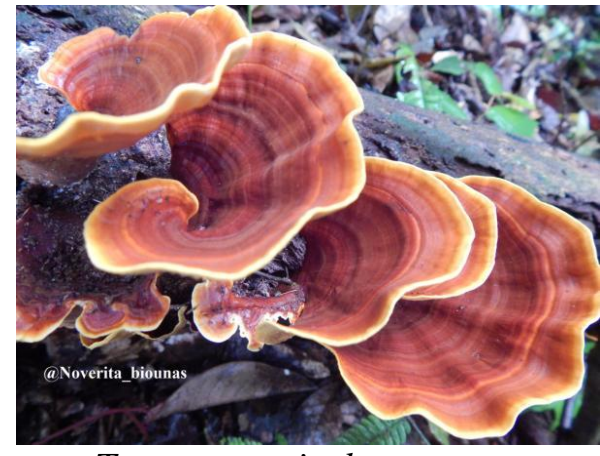

Trametes vesicolor

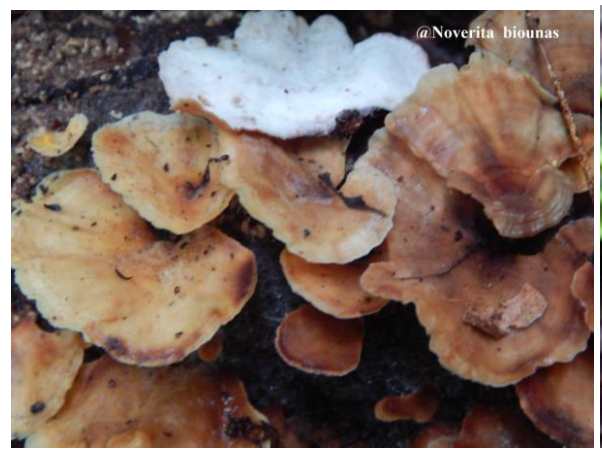

Microphorus sp.1

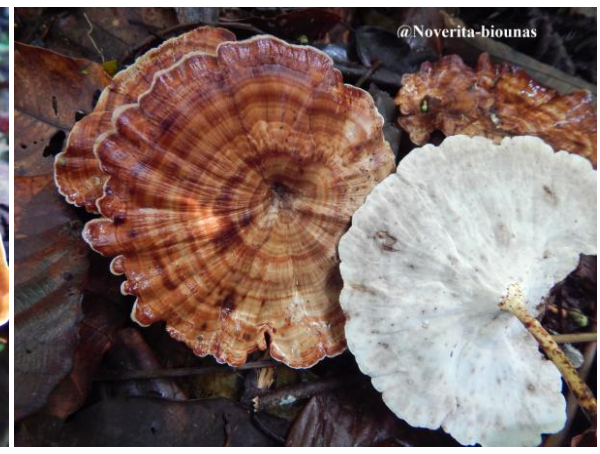

Microphorus xanthopus

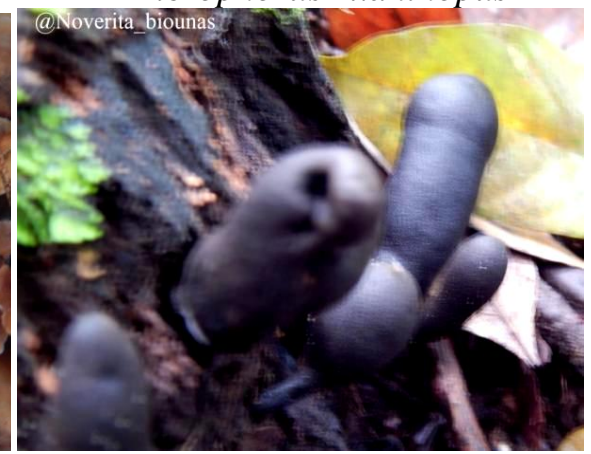

Xylaria polymorpha

Gambar 8. Beberapa jenis makrofungi yang berperan sebagai bahan obat yang ditemukan di lokasi penelitian.

Kawasan cagar alam Batang Palupuh banyak ditemukan tumbuhan liana, dibandingkan pohon besar. Liana dari jenis Tetrastigma lanceolarium merupakan inang tempat hidupnya Raflesia arnoldi karena kawasan ini merupakan kawasan endemik Raflesia, yang sering dikunjungi oleh wisatawan dalam dan luar negri. Kondisi ini akan mempengaruhi keberadaan mikoriza disekitar akar pohon besar tersebut. Sementara vegetasi dasarnya tidak banyak ditemukan anakan pohon, melainkan tanaman vegetasi dasar berupa tanaman herba dari suku Araceae seperti Elatostema latifolium, Schismatoglottis calyptrata, dan Homalomena rubra.

Jamur makro yang ditemukan di kedua kawasan ini secara umum didominasi oleh jenis yang bersifat saprofit pada kayu mati, hanya beberapa yang hidup parasit pada pohon hidup (tabel 2 dan 3). Jenis-jenis ini terutama masuk ke dalam bangsa Aphylloporales (Basidiomycota). Termasuk ke dalam kelompok ini adalah Amauroderma rugosum, Cymatoderma sp.1, Fomitopsis sp., Ganoderma spp., Heterobasidion annosum, Microphorus spp., Polyporus spp., Rigidoporus spp., dan Trametes spp. Menurut Tampubolon (2012). jamur makro dari bangsa Aphylloporales merupakan kelompok fungi yang mampu beradaptasi pada kondisi lingkungan yang kurang mendukung bagi pertumbuhannya. 
Selain bangsa Aphylloporales, di kedua kawasan ini juga didominasi oleh bangsa Agaricales. Jenis-jenis dari bangsa ini dicirikan dengan tubuh buah yang berupa payung, dan memiliki lamella (bilah) pada permukaan bawah payung dan batang/bilah. Biasanya di hutan ditemukan pada tempat yang lembab dan banyak naungan. Termasuk kedalam bangsa ini antara lain Amanita spp., Agaricus spp., Clitocybe spp., Entoloma spp., Filoboletus spp., Hygrocybe spp., Lepiota spp., Omphalina spp., Marasmius spp., Marasmiellus spp., dan Russula spp.

Kehadiran jamur dari kelompok jamur makro sangat penting bagi lingkungan atau habitat tempat tumbuhnya, serta manusia dan organisme lainnya. Di lingkungan hidupnya jamur makro hidup terutama sebagai saprofit yang berperan sebagai pengurai bahan-bahan organik mati seperti kayu mati atau kayu lapuk dan serasah, hasil penguraiannya berupa molekul-molekul sederhana yang dimanfaatkan sebagai sumber nutrisi bagi tumbuhan di sekitarnya. Pada umum jenis-jenis yang ditemukan di lapangan lebih dari $75 \%$ adalah jenis yang berperan sebagai pengurai bahan organik mati pada serasah maupun pada batang, cabang dan ranting kayu mati. Jenis-jenis yang tumbuh pada serasah terutama pada serasah daun didominasi oleh suku Marasmiaceae, dari marga Marasmius dan pada serasah ranting dan cabang kayu mati dari marga Marasmiellus dengan banyak jenis (gambar 4). Sementara itu jenis lain yang juga sangat berperan sebagai pengurai bahan organik mati terutama pada kayu-kayu besar, caba-cabang serta ranting di hutan, antara lain adalah suku Ganodermataceae (Ganoderma spp., Amauroderma rugosum), Polyporaceae (Polyporus spp., Microphorus spp., Trametes spp., dan Panus fasciatus) (gambar 5). Jamur makro di alam berperan sebagai dekomposer bersama bakteri untuk mempercepat siklus material dalam suatu ekosistem (Munir 2006).

Jamur makro-merupakan salah satu bahan pangan yang banyak digemari, terutama di negara-negara maju, karena kandungan gizi yang terdapat pada jamur makro tersebut. Beberapa contoh jamur makro yang sudah umum dikosumsi bahkan sudah dibudidayakan, diantaranya Agaricus bisporus, Auricularia auricula, Flamulina velutipes, Lentinus edodes, Pleurotus ostreatus, Tremella fuciformis, dan Volvariella volvacea. Di kedua kawasan penelitian ini ditemukan beberapa jenis jamur makro yang dapat dimakan dan sangat potensi untuk dikembangkan dalam bentuk budi daya, jenis-jenis tersebut diantaranya adalah $\mathrm{Au}$ ricularia auricula, A. delicata, Agaricus spp., Boletellus spp., Calvatia excipuliformis, Cantharellus cibarius, Cookeina speciosa, Fistulina sp., Hygrocybe sp.2, Lentinus sajor-caju, Marasmiellus ramealis, Russula fragilis, dan Pluteus cervinus (gambar 7). Selain berperan sebagai bahan pangan beberapa jenis yang ditemukan juga dapat dimanfaatkan sebagai bahan obat, jenis-jenis yang ditemukan sebagai bahan obat diantaranya adalah Amauroderma rugosum, Ganoderma lucidum, G. pfeifferi, G. resinaceum, Microphorus spp., Polyporus spp., Trametes spp., dan Xylaria spp. (gambar 8). Dari hasil wawancara dengan pemandu lapangan yang berasal dari petugas cagar alam dan masyarakat yang membantu sebagai pemandu di lapangan, di ketahui bahwa masyarakat yang ada di sekitar kawasan belum ada yang memanfaatkan jamur makro ini, baik sebagai bahan pangan maupun sebagai bahan obat. Hal ini mungkin disebabkan karena masyarakat setempat khususnya dan masyarakat Sumatera Barat pada umumnya lebih menyukai mengkonsumsi bahan pangan sebagai sumber protein yang berasal dari hewan, seperti ikan, ayam, sapi, kambing dan kerbau.

\section{Ucapan Terima Kasih}

Terimakasih kepada kepada Rektor dan Ketua LPPM Universitas Nasional yang telah memberikan bantuan dana sehingga penelitian ini dapat terlaksana dengan baik. 


\section{Pustaka}

Alexopoulus CJ, Mims CW and Blackwell M. 1996. Introductory of Mycology. Fourth Edition. John Wiley and Sons, New York.

Brundrett MC. 2008. Mycorrhizal Associations: The Web Resource. http://mycorrhizas.info/index.html

Brundrett M, Bougher N, Dell, Grove BT and Malajczuk N. 1995. Working with Mycorrhiza in Foresty and Agriculture. ACIAR Monograph. Australia.

BKSDA. 2007. Buku Informasi Kawasan Konservasi Propinsi Sumatra Barat. Departemen Kehutanan, Republik Indonesia.

Jusana SP, Fifendy M dan Periadnadi. 2013. Inventarisasi Jamur Tingkat Tinggi Di Kawasan Cagar Alam Lembah Anai Kabupaten Tanah Datar, Sumatera Barat. http://www.download.portalgaruda.org/article.php . Dikunjungi Agustus 2016

Deacon JW. 1997. Modern Mycology. Willey. Edinburgh.

Hilman H dan Romadoni A. 2001. Pengelolaan dan Perlindungan Aset Kekayaan Intelektual, Panduan bagi peneliti Bioteknologi, The British Council, Bandung hal. 1-24.

Largent D. 1973. How To Identify Mushrooms To Genus I: Macroscopic Features. Mad River Press. Inc. Route.Eureka California.

Pacioni G. 1994. Simon \& Schuster's Guide to Mushrooms. A Fireside Book Published By Simon \& Schuster Inc. New York.

Pegler DN.1983. AgaricFlora of the Lesser Antilles. Her Majest

Pegler DN.1983. AgaricFlora of the Lesser Antilles. Her Majest Stationery Office. Lonon.

Ryvarden L and Johansen I. 1980. A Preliminary Polypore Flora of East Africa. Fungiflor, Oslo, Norway.

Shu-Ting C and Milles PG. 2004. Mushrooms: Cultivation, Nutritional Value, Medical Effect, and Environmental Impact. CRC Press. New York.

Terri MB. 1999. Getting Started with Mushroom Cultivation, This article first appeared in Mushroom: the Journal of Wild Mushrooming. 